(c) American Dairy Science Association, 2006.

\title{
Effect of Total Mixed Ration Composition on Amino Acid Profiles of Different Fractions of Ruminal Microbes In Vitro
}

\author{
J. Boguhn, H. Kluth, and M. Rodehutscord ${ }^{1}$ \\ Institut für Ernährungswissenschaften, Martin-Luther-Universität Halle-Wittenberg, 06099 Halle (Saale), Germany
}

\begin{abstract}
The objective was to study the variation in the amino acid profile of microbial fractions obtained after feeding 16 total mixed rations for dairy cows in a Rusitec. Each ration was incubated for $15 \mathrm{~d}$ in 3 -fold replicate. The rations showed high variation in the inclusion level of different ingredients and the content of proximal nutrients, fiber fractions, and energy. Three microbial fractions were isolated by centrifugation. The reference microbes (RM) were isolated from the liquid effluent of vessels between $\mathrm{d} 7$ and 15 of incubation. Solid-associated microbes (SAM) were detached with methylcellulose from feed residues after incubation, and liquidassociated microbes (LAM) were obtained from the liquid content of the vessel. Both SAM and LAM were obtained only once for each vessel at the end of the incubation period. Across all rations, significant differences were found between RM, LAM, and SAM in amino acid concentration for some, but not all, amino acids. Within each microbial fraction, significant differences in the content of amino acids were found between rations. Multiple linear regression analysis did not show that the content of a certain nutrient or the inclusion rate of single feedstuffs could be used to predict the amino acid profile of microbial protein with an adequate level of accuracy. Further studies are necessary before the supply of individual microbial amino acids to the cows' duodenum can be modeled and predicted in dependence of diet data.
\end{abstract}

Key words: microbe, fraction, amino acid profile, prediction

\section{INTRODUCTION}

It has been shown that the duodenal flow of individual AA such as Met, Lys, or His can become a limiting factor for milk production or growth in cattle (Kim et al., 1999; Greenwood and Titgemeyer, 2000). The most important sources of AA at the duodenum of ruminants

Received April 15, 2005.

Accepted January 4, 2006

${ }^{1}$ Corresponding author: markus.rodehutscord@landw.uni-halle.de are the microbial crude protein $\left(\mathbf{C P}_{\mathbf{M}}\right)$ synthesized in the rumen, followed by RUP. Therefore, the amount and $\mathrm{AA}$ composition of $\mathrm{CP}_{\mathrm{M}}$ entering the duodenum are important factors that determine AA flow at the duodenum of dairy cows. Any attempt allowing a prediction of the individual AA flow at the duodenum in dependence of dietary factors may help improve the accuracy of yield prediction and diet formulation for cows with a special focus on high milk yield.

The review by Clark et al. (1992) indicated great differences in the AA composition of rumen bacteria with largely unknown reasons for these differences. The time of sampling after feeding did not influence the AA composition of microbial fractions (Cecava et al., 1990; Martin et al., 1996). However, manipulation of dietary factors (grain processing, forage-to-concentrate ratio, particle length) can alter the chemical composition of bacteria (Yang et al., 2001). Also, different feedstuffs (Korhonen et al., 2002), the content of crude fiber (Rodríguez-Prado et al., 2004), and different N sources (Atasoglu et al., 1999) might influence the AA profile of the $\mathrm{CP}_{\mathrm{M}}$. Likewise, details of the procedures used in different laboratories for isolating the microbes and analyzing their AA content contribute to the differences found between studies (Clark et al., 1992). Differences in the AA profile were found in vivo between different microbial fractions such as protozoa, liquid-associated microbes (LAM), and solid-associated microbes (SAM; Martin et al., 1994; Rodríguez et al., 2000).

Using TMR with variable composition, the present study intended to measure the AA profile in certain microbial fractions defined according to established isolation methods in vitro. We tried to identify, by regression analysis, dietary factors that may influence the AA profile of $\mathrm{CP}_{\mathrm{M}}$.

\section{MATERIALS AND METHODS}

A modified semicontinuous rumen simulation technique (Rusitec; Czerkawski and Breckenridge, 1977) was used. The experimental procedures and rations were described in detail in the companion paper by Boguhn et al. (2006). In brief, 16 TMR for dairy cows, designated $\mathrm{A}$ to $\mathrm{P}$, were investigated for fermentable crude nutrients and efficiency of $\mathrm{CP}_{\mathrm{M}}$ synthesis. The 
TMR contained at least one silage (corn or grass silage) and, apart from 3 roughage-only rations, at least one concentrate. Rations showed great variation in analyzed concentrations of proximal nutrients, NDF, ADF, and energy. The concentrations (in $\mathrm{g} / \mathrm{kg}$ of $\mathrm{DM}$ ) were between 874 and 947 for OM, 123 and 213 for CP, 159 and 282 for crude fiber (CF), and 20.3 and 47.6 for ether extract (EE). The NDF and ADF ranged from 290 to 552 and 163 to $314 \mathrm{~g} / \mathrm{kg}$ of DM, respectively. The concentration of ME as calculated from digestible crude nutrients ranged from 8.2 to $11.9 \mathrm{MJ} / \mathrm{kg}$ of DM. Three vessels per TMR were used in the Rusitec study. The continuous incubation period lasted for $15 \mathrm{~d}$. Each vessel contained 2 nylon bags with about $15 \mathrm{~g}$ of TMR, and every morning, one of the bags was replaced with a new one. Artificial saliva was continuously infused, and the liquid effluent from the vessel was quantitatively collected in an ice-cooled bottle.

\section{Separation of Microbes}

Three fractions of microbes were obtained as defined by the isolation method. From d 7 to 15 after start of the incubation, the so-called reference microbes (RM) were isolated from $320 \mathrm{~mL}$ of well-mixed liquid effluent by differential centrifugation according to Brandt and Rohr (1981). In brief, the liquid effluent was centrifuged (Suprafuge 22 from Heraeus Instruments, Hanau, Germany) twice at $2,000 \times \mathrm{g}$ and $4^{\circ} \mathrm{C}$ for $5 \mathrm{~min}$ to remove small feed particles. Then, the supernatant was centrifuged at $27,000 \times \mathrm{g}$ and $4^{\circ} \mathrm{C}$ for $15 \mathrm{~min}$. The remaining pellet was resuspended in $0.9 \%$ (wt/vol) $\mathrm{NaCl}$ solution, and centrifuged again. This was repeated twice. Following the last centrifugation step, the tube with the remaining microbial pellet was frozen, and the frozen pellets were subsequently freeze-dried. Freeze-dried samples from d 7 to 15 were pooled within the incubation vessel, and homogenized with pestle and mortar. This fraction of microbes is assumed to represent the complete bacterial population in the liquid effluent, because protozoa are largely removed together with small feed particles in the first centrifugation step (Brandt and Rohr, 1981).

Solid-associated microbes were obtained using a modified procedure of Carro and Miller (2002) following Minato and Suto (1978). At the end of the incubation period on $d 15$, the 2 nylon bags containing the feed residue were removed from the vessel, washed twice with $40 \mathrm{~mL}$ of artificial saliva, and incubated with 240 $\mathrm{mL}$ of a saline solution of methylcellulose ( $1 \mathrm{~g}$ of methylcellulose $+9 \mathrm{~g}$ of $\mathrm{NaCl} / \mathrm{L}$ of distilled water) at $39^{\circ} \mathrm{C}$ for $30 \mathrm{~min}$ in a beaker to elute attached microbes. Then the bags were gently squeezed and washed twice with the same solution. The suspension was quickly cooled by the addition of $500 \mathrm{~mL}$ of a cold $\left(4^{\circ} \mathrm{C}\right) \mathrm{NaCl}$ solution $(0.9 \% \mathrm{wt} / \mathrm{vol})$ containing $0.1 \%$ (wt/vol) methylcellulose. This mix was stored at $4^{\circ} \mathrm{C}$ for a minimum of $6 \mathrm{~h}$ before SAM were isolated by differential centrifugation with the same procedure described above for RM.

The liquid content of the vessel at the end of the incubation, including the liquid residue from the feed bag washing, was used to isolate LAM. The suspension was mixed and centrifuged twice at $2,000 \times \mathrm{g}$ and $4^{\circ} \mathrm{C}$ for $5 \mathrm{~min}$. Further centrifugation steps were the same as described above for RM. Both SAM and LAM fractions were frozen at $-18^{\circ} \mathrm{C}$ after the last centrifugation step, freeze-dried, and pulverized with a pestle and mortar. In contrast to the RM fraction, which was continuously separated and collected from the liquid effluent between $\mathrm{d} 7$ and 15, LAM was an end-point measure only. Also, LAM may contain loosely associated microbes that were detached from the feed residue during the washing process.

Based on these details it can be assumed that the 3 microbial fractions overlapped in regard to the species they contained.

\section{Chemical and Statistical Analyses}

The $\mathrm{N}$ content of the microbial fractions was determined in percentage of freeze-dried substance by an elementary analyzer (Vario EL, Elementar Analysensysteme GmbH, Hanau, Germany) in conjunction with ${ }^{15} \mathrm{~N}$ analyses (Boguhn et al., 2006). Amino acid analysis followed the official method for feed (Naumann and Bassler, 1976) described in detail by Timmler and Rodehutscord (2003). After an oxidation step, samples were hydrolyzed in $6 \mathrm{~N} \mathrm{HCl}$. Norleucine was used as the external standard. Tryptophan, His, and Tyr were not determined after this hydrolysis (Mason et al., 1980). Separation of AA was made with an amino acid analyzer (LC 3000, Eppendorf Biotronik, Maintal,

Germany) using different buffer solutions and ninhydrin. For calibration, an AA standard solution by Sigma Aldrich Chemie, Taufkirchen, Germany was used (2.5 $\mu \mathrm{mol}$ of AA per $\mathrm{mL}$ of solution, except for cystine: 1.25 $\mu \mathrm{mol} / \mathrm{mL}$ ). It was intended to use about $100 \mathrm{mg}$ of freeze-dried material of each sample for analysis, which is equivalent to about $10 \mathrm{mg}$ of $\mathrm{N}$. However, the sample size of the SAM fraction was low and often insufficient for a replicated analysis. Therefore, for some samples, only one measurement using $<100 \mathrm{mg}$ of sample was available from the SAM fraction.

Concentrations of AA in the microbial fractions were first expressed in g/16 g of N. However, Trp, His, and Tyr were not analyzed, and the AA concentrations expressed this way may be affected by non-AA $\mathrm{N}$ fractions in the samples. For comparison of the AA pattern, we 
Table 1. Amino acid concentrations ${ }^{1}$ ( $\mathrm{g}$ of AA/100 $\mathrm{g}$ of analyzed AA) determined in microbial fractions $(\mathrm{n}=$ 16 , mean and SD) and total analyzed amino acid (TAA) content

\begin{tabular}{|c|c|c|c|c|c|c|c|}
\hline \multirow[b]{3}{*}{ Amino acid } & \multicolumn{6}{|c|}{ Microbial fraction $^{2}$} & \multirow[b]{3}{*}{$P$} \\
\hline & \multicolumn{2}{|c|}{$\mathrm{RM}$} & \multicolumn{2}{|c|}{ LAM } & \multicolumn{2}{|c|}{ SAM } & \\
\hline & Mean & SD & Mean & $\mathrm{SD}$ & Mean & SD & \\
\hline Ala & $10.37^{\mathrm{a}}$ & 0.32 & $10.28^{\mathrm{a}}$ & 0.47 & $9.75^{\mathrm{b}}$ & 0.66 & $<0.01$ \\
\hline Arg & 14.21 & 0.82 & 13.63 & 0.97 & 13.43 & 1.34 & 0.11 \\
\hline Asp & $9.98^{\mathrm{a}}$ & 0.21 & $9.97^{\mathrm{a}}$ & 0.20 & $9.72^{\mathrm{b}}$ & 0.36 & 0.01 \\
\hline Cys & $0.93^{\mathrm{a}}$ & 0.04 & $0.97^{\mathrm{a}}$ & 0.09 & $1.12^{\mathrm{b}}$ & 0.22 & $<0.01$ \\
\hline Glu & $9.87^{\mathrm{a}}$ & 0.18 & $10.00^{\mathrm{a}}$ & 0.26 & $10.63^{\mathrm{b}}$ & 0.64 & $<0.01$ \\
\hline Gly & $8.12^{\mathrm{a}}$ & 0.20 & $7.89^{b}$ & 0.17 & $7.92^{\mathrm{ab}}$ & 0.33 & 0.03 \\
\hline Ile & 4.49 & 0.15 & 4.60 & 0.10 & 4.50 & 0.18 & 0.08 \\
\hline Leu & $6.61^{\mathrm{a}}$ & 0.12 & $6.67^{\mathrm{a}}$ & 0.09 & $7.04^{\mathrm{b}}$ & 0.21 & $<0.01$ \\
\hline Lys & $11.60^{\mathrm{a}}$ & 0.60 & $12.20^{\mathrm{b}}$ & 0.57 & $11.18^{\mathrm{a}}$ & 0.68 & $<0.01$ \\
\hline Met & $1.79^{\mathrm{ab}}$ & 0.08 & $1.87^{\mathrm{b}}$ & 0.07 & $1.73^{\mathrm{a}}$ & 0.12 & $<0.01$ \\
\hline Phe & $3.30^{\mathrm{a}}$ & 0.11 & $3.39^{\mathrm{ab}}$ & 0.15 & $3.54^{\mathrm{b}}$ & 0.25 & $<0.01$ \\
\hline Pro & $3.44^{\mathrm{a}}$ & 0.33 & $3.43^{\mathrm{a}}$ & 0.22 & $4.18^{\mathrm{b}}$ & 0.39 & $<0.01$ \\
\hline Ser & $4.25^{\mathrm{a}}$ & 0.06 & $4.18^{\mathrm{a}}$ & 0.12 & $4.48^{\mathrm{b}}$ & 0.19 & $<0.01$ \\
\hline Thr & $5.07^{\mathrm{a}}$ & 0.10 & $4.94^{\mathrm{b}}$ & 0.10 & $4.79^{\mathrm{c}}$ & 0.21 & $<0.01$ \\
\hline Val & 5.97 & 0.08 & 5.98 & 0.22 & 6.01 & 0.27 & 0.89 \\
\hline TAA $(g / 16 g$ of $N)$ & 64.45 & 2.32 & 67.42 & 2.42 & 65.15 & 2.92 & \\
\hline
\end{tabular}

${ }^{a-c}$ Means with different superscripts within a row differ significantly $(P<0.05)$.

${ }^{1}$ Trp, His, and Tyr were not determined.

${ }^{2} \mathrm{RM}=$ Reference microbes; LAM = liquid-associated microbes; and SAM = solid-associated microbes.

therefore used the relation between each individual AA and the sum of all analyzed AA and expressed it as g/ $100 \mathrm{~g}$ of analyzed AA.

Results were subjected to the GLM procedure using the software package SAS for Windows (version 9.1, SAS Institute Inc., Cary, NC). Significant differences between TMR were detected by $t$-test $(P \leq 0.05)$.

Multiple linear regressions were calculated with the REG procedure to identify factors that influenced the AA content of $\mathrm{CP}_{\mathrm{M}}$ fractions. The values of $\mathrm{R}^{2}$ and $P$ will be given as a measure for the goodness of fit. Relevant factors that influenced the composition of $\mathrm{CP}_{\mathrm{M}}$ were detected by using the $P$ values of partial correlation $\left(\boldsymbol{P}_{\boldsymbol{p}}\right)$ according the SAS software. The $P_{p}$ described the influence of each factor on the focused value (here: each AA). On the other hand, the global $P$ value $(P)$ expressed the meaning of the sum of factors. As variables that may affect the $\mathrm{AA}$ composition of $\mathrm{CP}_{\mathrm{M}}$, first the content of nutrients, and second, the inclusion rates of corn and grass silage in the diets were considered. The latter were chosen because they were contained in 15 out of the 16 TMR studied.

\section{RESULTS}

\section{Comparison of the Microbial Fractions}

The AA composition of the 3 microbial fractions, pooled across all TMR, is shown in Table 1. The LAM fraction contained significantly less Gly and Thr, but more Lys, than the RM fraction, whereas the other AA were not significantly different. Significant differences between RM and SAM were found for 9 AA. The contents of Cys, Glu, Leu, Phe, Pro, and Ser were higher in SAM than in RM, whereas the opposite was found for Ala, Asp, and Thr (Table 1).

\section{Effect of TMR Within the Microbial Fraction}

Differences were found in the AA profile between the 16 TMR, as shown for the RM fraction in Figure 1. Some TMR that were composed of identical feedstuffs in varying proportions did not show different AA profiles (e.g., TMR G and H, or E and I, except Lys). On the other hand, TMR with similar nutrient and energy contents, but based on different ingredients, showed significant differences (TMR J and G). Some TMR caused significant differences in the AA profile of RM, although they consisted of different feedstuffs and had different concentrations of energy and nutrients (TMR M and N). Similar differences were measured for the LAM fraction (Table 2).

Due to the aforementioned shortage in sample size, the AA content of SAM showed large standard deviations for all TMR (Table 3). In spite of this, the data indicate that when TMR contained the same feedstuffs, no differences existed in the AA profile of this fraction. Also, the variation in the content of individual AA in SAM protein could not be explained by the nutrient content of TMR. 

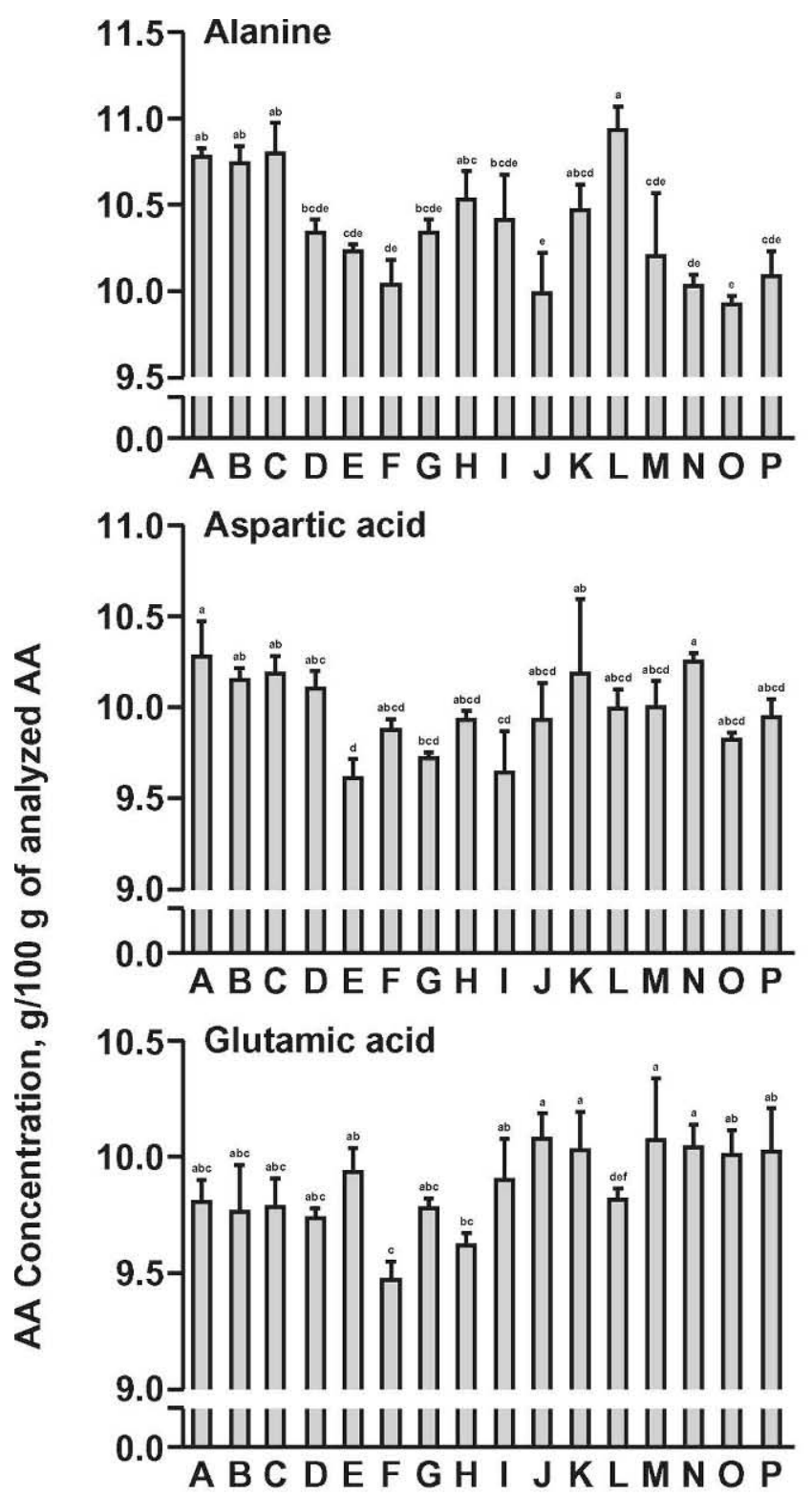

5.0 Isoleucine

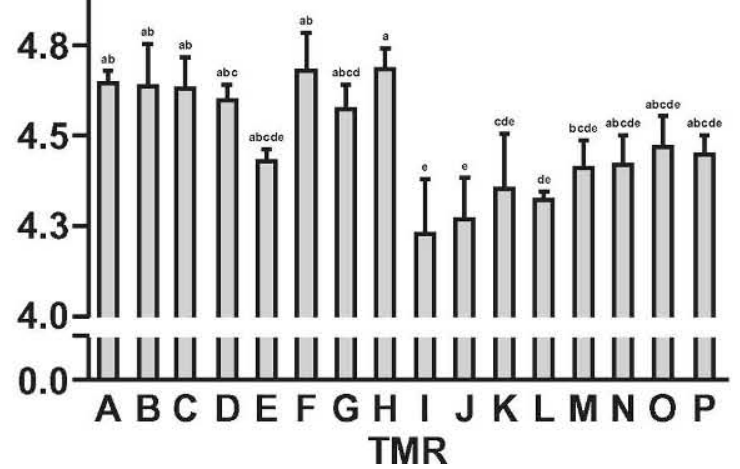

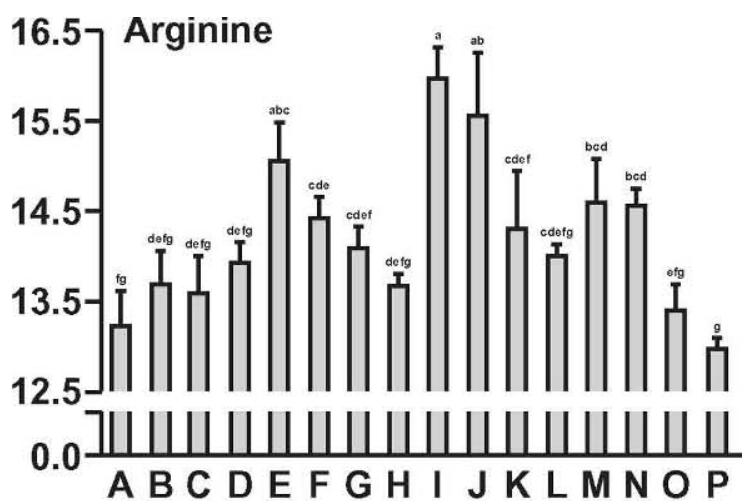

1.2] Cystine

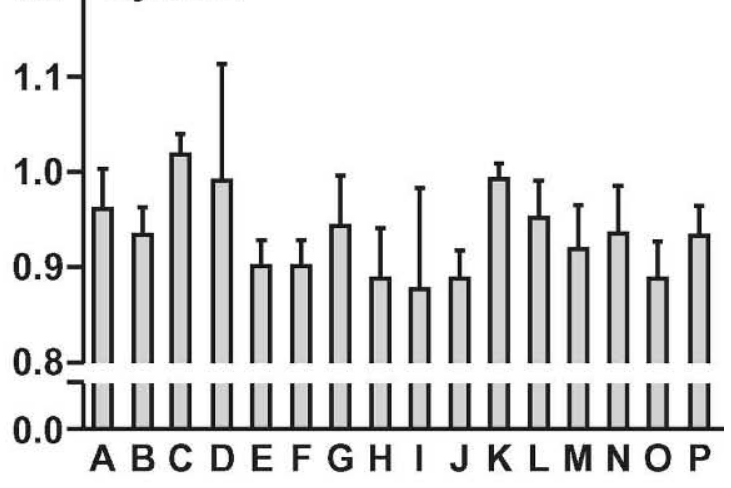

9.0 Glycine
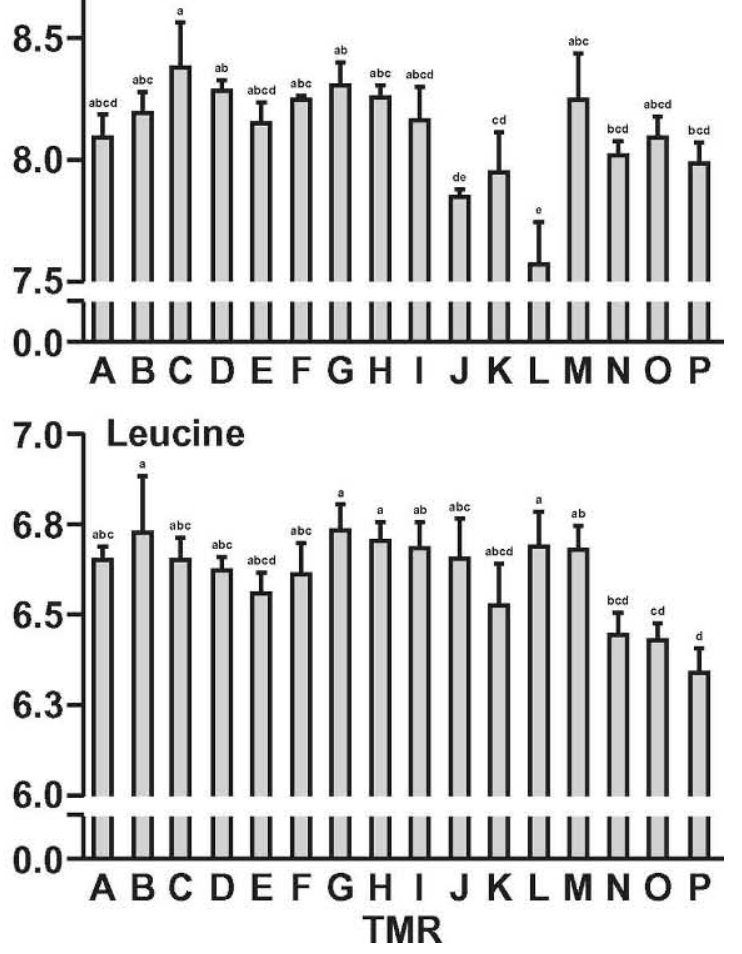

Figure 1. Amino acid concentration ( $\mathrm{g} / 100 \mathrm{~g}$ of analyzed AA) of protein from reference microbes isolated after using 16 TMR in a Rusitec study ( $\mathrm{n}=3$ per TMR). ${ }^{\mathrm{a}-\mathrm{g}}$ Columns not sharing a common superscript are significantly different $(P \leq 0.05)$. 

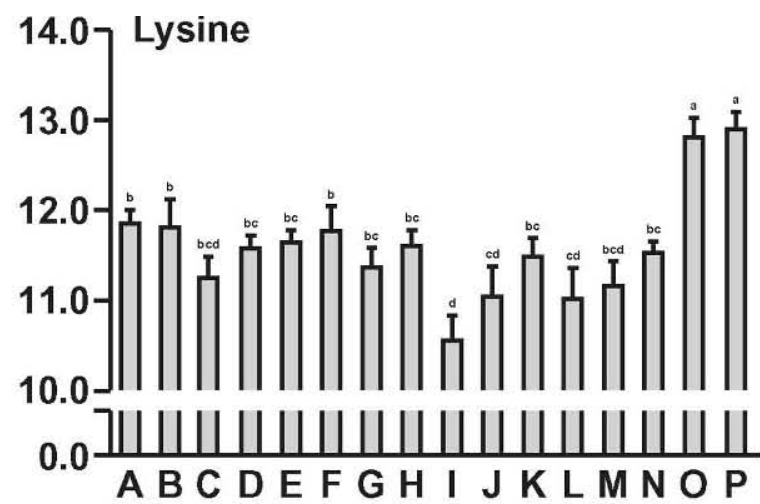

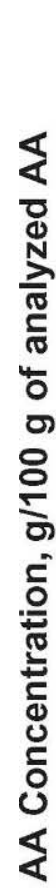

4.0 Phenylalanine

$3.5-$

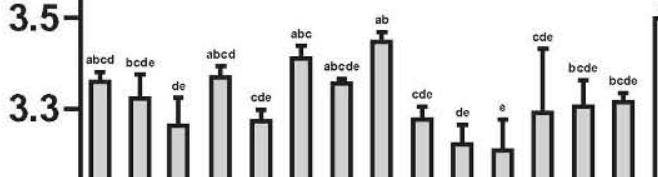
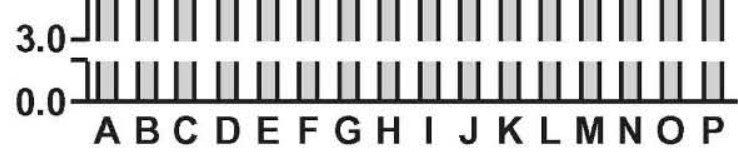

4.8 Serine

$4.6-$

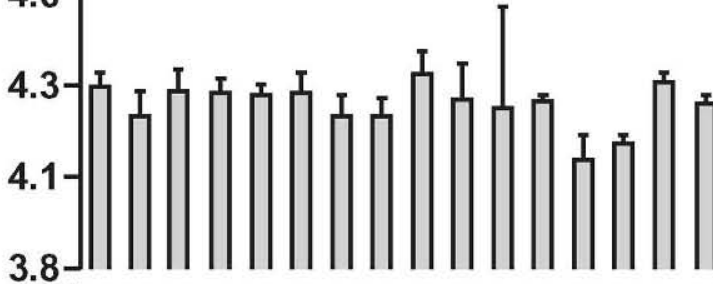

0.0Ш山ШШШШШШШШШШШШШ

6.57 Valine

$6.3-$

5.8-5 -

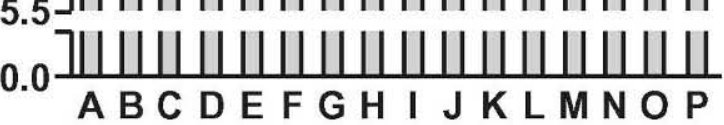

TMR
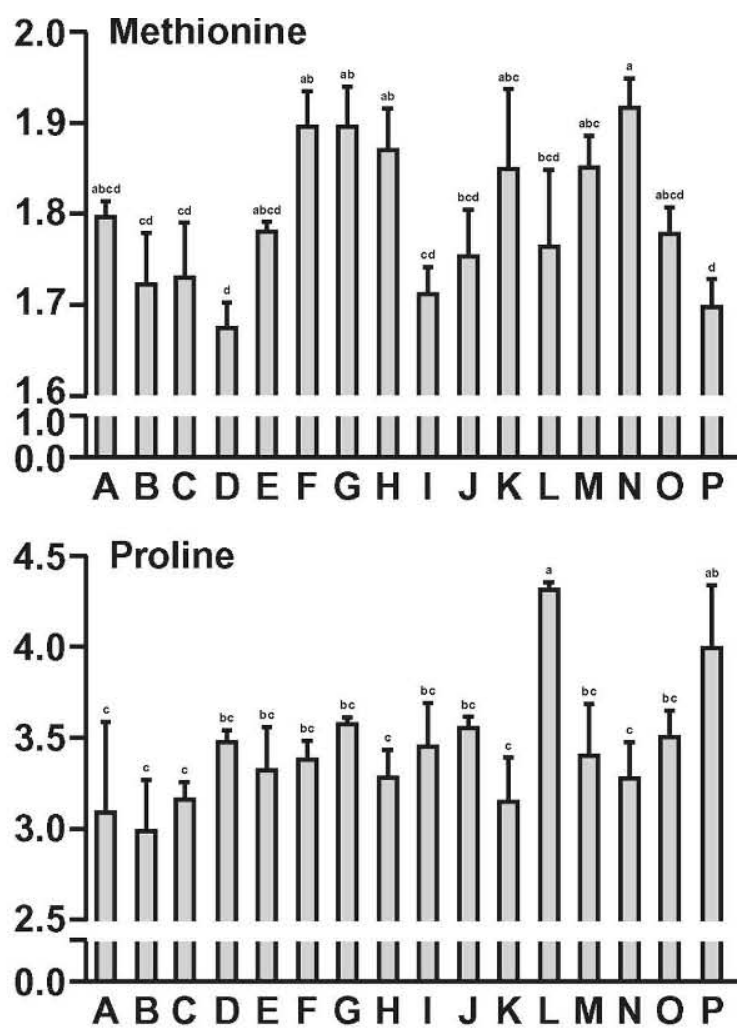

5.5 Threonine

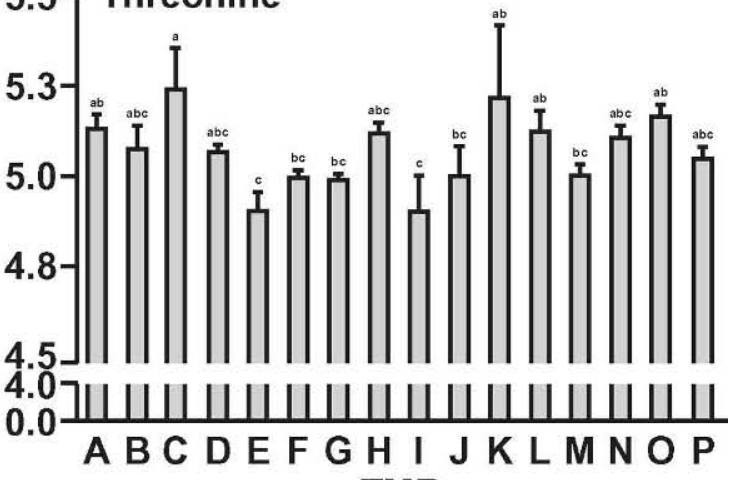
TMR

Figure 1 (Continued). Amino acid concentration ( $\mathrm{g} / 100 \mathrm{~g}$ of analyzed AA) of protein from reference microbes isolated after using 16 TMR in a Rusitec study ( $\mathrm{n}=3$ per TMR). ${ }^{\mathrm{a}-\mathrm{g}}$ Columns not sharing a common superscript are significantly different $(P \leq 0.05)$. 
Table 2. Content of amino acids ${ }^{1}$ in liquid-associated microbes and total analyzed amino acid (TAA) content $(\mathrm{n}=3$, means and SD)

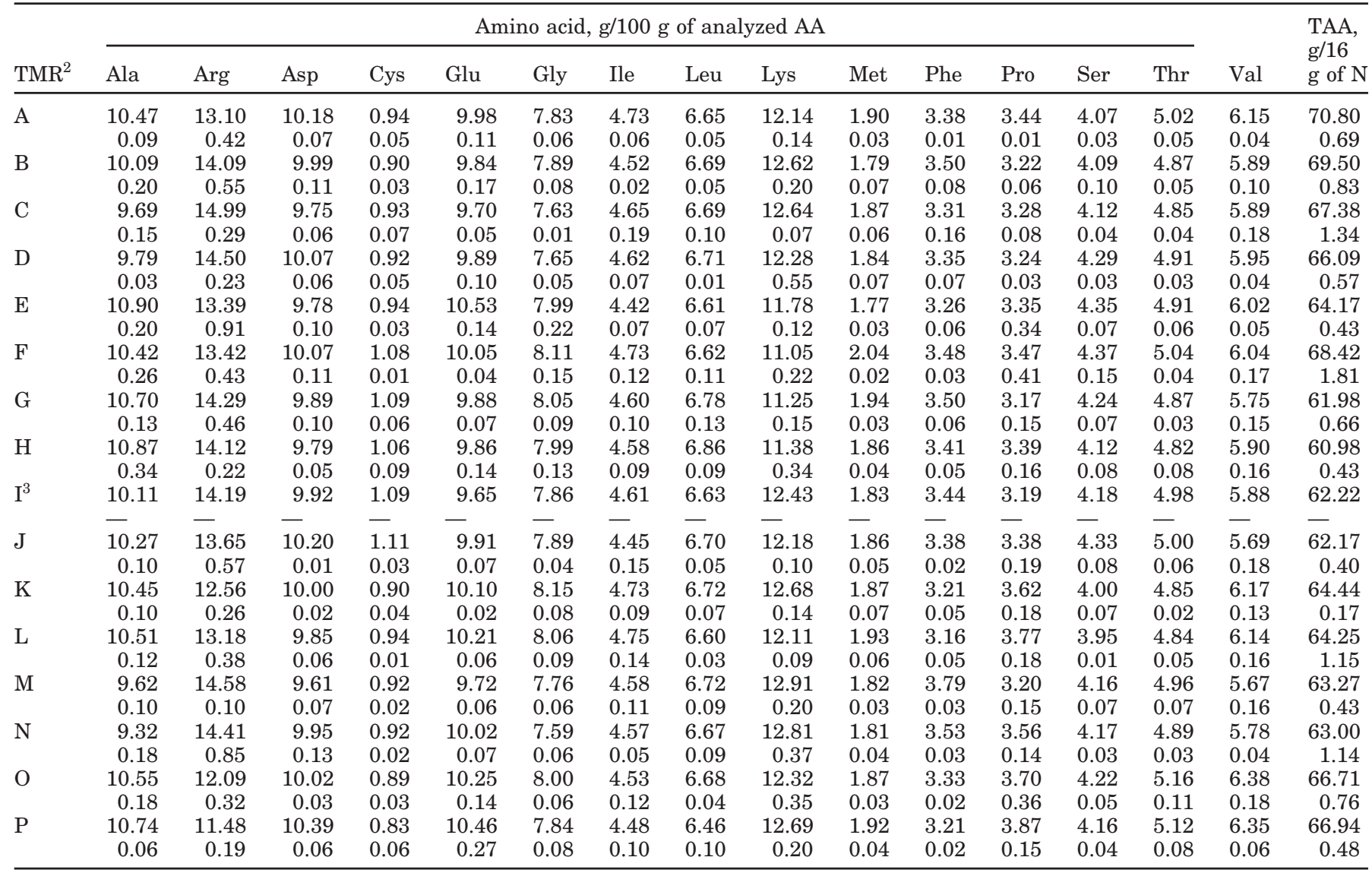

\footnotetext{
${ }^{1}$ Trp, His, and Tyr were not determined.

${ }^{2}$ Code according to Boguhn et al. (2006).

${ }^{3} \mathrm{n}=2$.
}

\section{Factors Influencing the Composition of $\mathrm{CP}_{M}$}

Regressions were calculated to identify factors that may influence the AA content. Results are only presented for the fractions RM and SAM, because LAM differed in AA composition only little from RM (Table 1 ), and the fraction $R M$ is regarded as the bacterial fraction with the least contamination by feed particles (Brandt and Rohr, 1981).

Table 4 shows equations that were calculated to predict the AA profile in the RM fraction. In a few cases, the content of CF significantly affected the content of individual AA such as Arg, Asp, Lys, Ser, and Thr, as judged by the partial $P$-value $\left(P_{p} \leq 0.1\right)$. Other single nutrients significantly contributed to the accuracy of prediction in no case more than once. Considering all nutrients together, the accuracy of prediction was high for Arg, Asp, Cys, and Thr (global $P<0.1$ ). When NDF or $\mathrm{ADF}$ instead of $\mathrm{CF}$ was considered as the independent variable, a significant effect was found for only 3 instead of 5 individual AA (data not shown). Possible effects of inclusion rates of grass and corn silage in the TMR were also tested. The grass silage inclusion rate had a significant effect on the contents of Ala, Gly, and Met $\left(P_{p}<0.1\right)$, and the corn silage inclusion rate on Gly and Phe.

Contents of individual AA in the SAM fraction were affected by a certain nutrient $\left(P_{p}<0.1\right)$ in only a very few cases (Ala, Gly; Table 5). However, the global $P$ values indicated that a prediction of individual AA such as Ala, Glu, Gly, Ile, and Met may be possible (global $P<0.10$ ) based on all considered nutrients together. The inclusion rate of total roughages in TMR did significantly influence the contents of Ala, Glu, Gly, Ile, and Val $\left(P_{p}<0.1\right)$. Except for Arg, Asp, Cys, Lys, Met, Pro, Ser, and Thr, the accuracy of prediction was high (global $P<0.10$ ) when inclusion rates of roughages were considered.

\section{DISCUSSION}

In early studies on this subject, the AA composition of microbes isolated from the rumen has been reported 
Table 3. Content of amino acids ${ }^{1}$ in solid-associated microbes and total analyzed amino acid (TAA) content ( $\mathrm{n}=3$, means and SD)

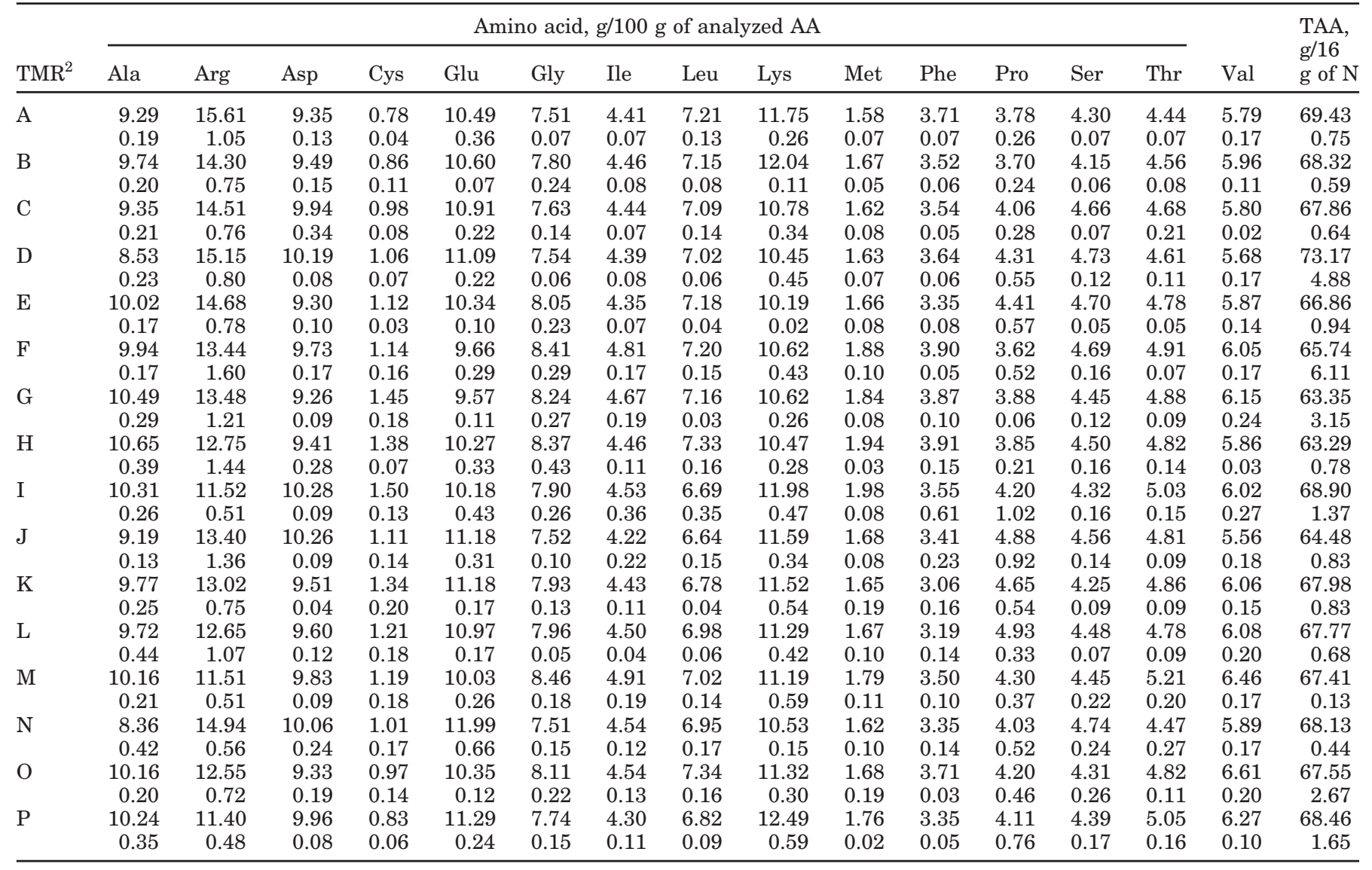

\footnotetext{
${ }^{1}$ Trp, His, and Tyr were not determined.
}

${ }^{2}$ Code according to Boguhn et al. (2006).

to be relatively constant (Meyer et al., 1967; Bergen et al., 1968; Hoogenraad and Hird, 1970; Ibrahim and Ingalls, 1972; Storm and Ørskov, 1983). The review by Clark et al. (1992), however, showed great variation in AA composition of bacterial protein. Part of this variation may be caused by differences between studies in the manner of sampling microbes, the isolation technique, details of chemical analyses, or the way of expressing results. Variation in the AA profile of microbial protein remains even when the review is limited to data that originate from one laboratory only (Clark et al., 1992).

In trials that comprised a broad range of different diets, marked differences in AA composition of protein from mixed rumen microbes were detected (Hvelplund, 1986). Martin et al. (1996), however, reported negligible diet effects on the AA profile of LAM and SAM proteins. Single feedstuffs in mixed rations for dairy cows such as barley and rapeseed meal did not influence the AA profile of the different microbial fractions in vivo (Korhonen et al., 2002). If the AA composition of different microbial fractions is not the same, dietary factors that induce variation in the relative contribution of SAM, LAM, and protozoa to the total microbial outflow give rise to differences in the $\mathrm{AA}$ profile of the microbial protein flowing to the duodenum (Dijkstra et al., 1997). Although some models in calculating the duodenal AA flow differ between $\mathrm{CP}_{\mathrm{M}}$ and RUP, the AA composition of $\mathrm{CP}_{\mathrm{M}}$ is assumed constant (O'Connor et al., 1993; Lescoat and Sauvant, 1995). All models tested by Bateman et al. (2001) were sufficiently accurate in predicting the amount of protein from microbes and feed that reached the duodenum if the diet composition changed. However, no variable was significantly relevant for the estimation of $\mathrm{CP}$ or AA passage to the small intestine.

In vitro studies such as the present one indicate that the composition of the microbial population is altered by the composition of the ration, and subsequently, the AA profile is changed (Hannah et al., 1986; Guzzon et al., 1997). Calsamiglia et al. (1995) reported that an isonitrogenous inclusion of different protein sources in diets (e.g., corn gluten meal, hydrolyzed feather meal, and blood meal) not only altered the total flow of essential AA from the fermenter, due to different AA pattern 
Table 4. Equations calculated to predict the AA content of reference microbes (g/100 g of analyzed AA), including partial $P$-values $(\mathrm{n}=16$, nutrients in $\mathrm{g} / \mathrm{kg}$ of $\mathrm{DM})$

\begin{tabular}{|c|c|c|c|c|c|c|c|c|c|c|c|c|c|c|c|c|}
\hline \multirow{9}{*}{$\begin{array}{l}\text { Intercept } \\
\text { OM } \\
\mathrm{CP} \\
\text { Crude fiber } \\
\text { Ether extract } \\
P \\
\mathrm{R}^{2} \\
\mathrm{CV} \%\end{array}$} & \multicolumn{2}{|c|}{ Ala } & \multicolumn{2}{|c|}{ Arg } & \multicolumn{2}{|c|}{ Asp } & \multicolumn{2}{|c|}{ Cys } & \multicolumn{2}{|c|}{ Glu } & \multicolumn{2}{|c|}{ Gly } & \multicolumn{2}{|c|}{ Ile } & \multicolumn{2}{|c|}{ Leu } \\
\hline & 0.3369 & 0.97 & -11.6758 & 0.52 & 12.0900 & $<0.01$ & 1.0281 & 0.15 & 16.7683 & $<0.01$ & 16.1369 & 0.01 & 7.3424 & 0.10 & 3.8172 & 0.28 \\
\hline & 0.0097 & 0.19 & 0.0203 & 0.21 & -0.0016 & 0.56 & -0.0001 & 0.85 & -0.0050 & 0.19 & -0.0076 & 0.13 & -0.0029 & 0.43 & 0.0021 & 0.47 \\
\hline & 0.0058 & 0.42 & 0.0210 & 0.19 & 0.0014 & 0.60 & 0.0005 & 0.38 & -0.0065 & 0.10 & -0.0040 & 0.41 & -0.0007 & 0.85 & 0.0029 & 0.34 \\
\hline & 0.0014 & 0.77 & 0.0250 & 0.03 & -0.0036 & 0.07 & -0.0006 & 0.15 & -0.0042 & 0.11 & -0.0025 & 0.44 & -0.0017 & 0.48 & 0.0023 & 0.25 \\
\hline & -0.0042 & 0.72 & -0.0456 & 0.09 & -0.0043 & 0.34 & 0.0012 & 0.24 & -0.0092 & 0.15 & 0.0035 & 0.66 & 0.0071 & 0.24 & -0.0037 & 0.45 \\
\hline & & 0.31 & & 0.08 & & $<0.01$ & & $<0.01$ & & 0.19 & & 0.48 & & 0.56 & & 0.76 \\
\hline & & 0.33 & & 0.51 & & 0.77 & & 0.73 & & 0.40 & & 0.25 & & 0.22 & & 0.15 \\
\hline & & 2.94 & & 4.74 & & 1.17 & & 2.68 & & 1.61 & & 2.55 & & 3.46 & & 1.92 \\
\hline Intercept & 10.0144 & $<0.01$ & 15.9734 & $<0.01$ & 10.4181 & $<0.01$ & 0.9629 & $<0.01$ & 10.1840 & $<0.01$ & 7.9440 & $<0.01$ & 4.2913 & $<0.01$ & 6.5672 & $<0.01$ \\
\hline $\mathrm{GS}^{1}$ & -0.0160 & $<0.01$ & 0.0159 & 0.26 & -0.0019 & 0.63 & -0.0011 & 0.17 & 0.0021 & 0.56 & 0.0067 & 0.08 & 0.0012 & 0.68 & -0.0013 & 0.61 \\
\hline $\mathrm{CS}^{2}$ & -0.0106 & 0.11 & -0.0200 & 0.28 & -0.0022 & 0.67 & -0.0007 & 0.48 & 0.0016 & 0.74 & 0.0093 & 0.07 & 0.0045 & 0.27 & -0.0026 & 0.44 \\
\hline $\mathrm{RO}^{3}$ & 0.0157 & 0.05 & -0.0238 & 0.26 & -0.0041 & 0.49 & 0.0004 & 0.76 & -0.0056 & 0.32 & -0.0040 & 0.46 & 0.0005 & 0.91 & 0.0020 & 0.60 \\
\hline$P$ & & 0.03 & & 0.08 & & 0.32 & & 0.28 & & 0.74 & & 0.13 & & 0.53 & & 0.88 \\
\hline $\mathrm{R}^{2}$ & & 0.53 & & 0.41 & & 0.24 & & 0.27 & & 0.10 & & 0.36 & & 0.16 & & 0.05 \\
\hline \multirow[t]{2}{*}{ CV\% } & & 2.37 & & 4.96 & & 2.03 & & 4.27 & & 1.90 & & 2.26 & & 3.43 & & 1.94 \\
\hline & \multicolumn{2}{|c|}{ Lys } & \multicolumn{2}{|c|}{ Met } & \multicolumn{2}{|c|}{ Phe } & \multicolumn{2}{|c|}{ Pro } & \multicolumn{2}{|c|}{ Ser } & \multicolumn{2}{|c|}{ Thr } & \multicolumn{2}{|c|}{ Val } & & \\
\hline Intercept & 35.2264 & 0.04 & 3.0854 & 0.14 & 5.9916 & 0.07 & -5.4904 & 0.58 & 0.8500 & 0.54 & 7.2625 & 0.01 & 7.2677 & 0.01 & & \\
\hline $\mathrm{OM}$ & -0.0184 & 0.17 & -0.0016 & 0.35 & -0.0024 & 0.38 & 0.0075 & 0.38 & 0.0030 & 0.02 & -0.0017 & 0.36 & -0.0014 & 0.49 & & \\
\hline $\mathrm{CP}$ & -0.0243 & 0.08 & 0.0006 & 0.72 & -0.0024 & 0.37 & 0.0054 & 0.52 & 0.0015 & 0.21 & -0.0013 & 0.48 & 0 & 0.99 & & \\
\hline Crude fiber & -0.0178 & 0.06 & 0.0004 & 0.76 & -0.0014 & 0.43 & 0.0039 & 0.50 & 0.0015 & 0.09 & -0.0025 & 0.07 & -0.0002 & 0.86 & & \\
\hline Ether extract & 0.0332 & 0.14 & 0.0005 & 0.86 & 0.0048 & 0.28 & 0.0109 & 0.43 & 0.0011 & 0.56 & 0.0037 & 0.23 & 0.0013 & 0.69 & & \\
\hline & & 0.28 & & 0.30 & & 0.74 & & 0.77 & & 0.11 & & 0.08 & & 0.80 & & \\
\hline $\mathrm{R}^{2}$ & & 0.35 & & 0.34 & & 0.15 & & 0.14 & & 0.47 & & 0.51 & & 0.13 & & \\
\hline CV\% & & 4.85 & & 4.11 & & 3.46 & & 10.49 & & 1.20 & & 1.58 & & 1.47 & & \\
\hline Intercept & 10.5748 & $<0.01$ & 1.7974 & $<0.01$ & 3.0141 & $<0.01$ & 3.0125 & $<0.01$ & 4.1907 & $<0.01$ & 5.0489 & $<0.01$ & 6.0011 & $<0.01$ & & \\
\hline GS & 0.0024 & 0.83 & 0.0029 & 0.04 & 0.0008 & 0.61 & -0.0103 & 0.13 & -0.0017 & 0.16 & -0.0018 & 0.34 & 0.0020 & 0.23 & & \\
\hline CS & 0.0215 & 0.16 & 0.0013 & 0.46 & 0.0047 & 0.05 & -0.0084 & 0.34 & -0.0007 & 0.65 & 0.0010 & 0.69 & 0.0014 & 0.51 & & \\
\hline RO & 0.0051 & 0.76 & -0.0018 & 0.35 & 0.0018 & 0.49 & 0.0132 & 0.20 & 0.0018 & 0.33 & 0.0008 & 0.76 & -0.0018 & 0.48 & & \\
\hline$P$ & & 0.28 & & 0.08 & & 0.04 & & 0.48 & & 0.44 & & 0.35 & & 0.62 & & \\
\hline $\mathrm{R}^{2}$ & & 0.26 & & 0.42 & & 0.48 & & 0.18 & & 0.20 & & 0.23 & & 0.13 & & \\
\hline CV\% & & 4.93 & & 3.67 & & 2.60 & & 9.81 & & 1.42 & & 1.89 & & 1.40 & & \\
\hline
\end{tabular}

${ }^{1} \mathrm{GS}=$ Inclusion rate of grass silage in $\%$ of DM.

${ }^{2} \mathrm{CS}=$ Inclusion rate of corn silage in $\%$ of $\mathrm{DM}$.

${ }^{3} \mathrm{RO}=$ Inclusion rate of total roughages in \% of DM. 
Table 5. Equations calculated to predict the AA content of solid-associated microbes ( $\mathrm{g} / 100 \mathrm{~g}$ of analyzed AA), including partial $P$-values (n $=16$, nutrients in g/kg of DM)

\begin{tabular}{|c|c|c|c|c|c|c|c|c|c|c|c|c|c|c|c|c|}
\hline \multirow{9}{*}{$\begin{array}{l}\text { Intercept } \\
\text { OM } \\
\mathrm{CP} \\
\text { Crude fiber } \\
\text { Ether extract } \\
P \\
\mathrm{R}^{2} \\
\mathrm{CV} \%\end{array}$} & \multicolumn{2}{|c|}{ Ala } & \multicolumn{2}{|c|}{ Arg } & \multicolumn{2}{|c|}{ Asp } & \multicolumn{2}{|c|}{ Cys } & \multicolumn{2}{|c|}{ Glu } & \multicolumn{2}{|c|}{ Gly } & \multicolumn{2}{|c|}{$11 \mathrm{e}$} & \multicolumn{2}{|c|}{$\mathrm{u}$} \\
\hline & 18.6390 & 0.17 & -3.3303 & 0.93 & 1.5328 & 0.88 & -2.8349 & 0.61 & 9.0074 & 0.51 & 16.8740 & 0.02 & 8.7227 & 0.02 & 14.6362 & 0.03 \\
\hline & -0.0067 & 0.55 & 0.0130 & 0.67 & 0.0066 & 0.47 & 0.0027 & 0.58 & 0.0044 & 0.70 & -0.0092 & 0.09 & -0.0052 & 0.08 & -0.0070 & 0.20 \\
\hline & -0.0200 & 0.09 & 0.0306 & 0.32 & 0.0093 & 0.31 & 0.0028 & 0.56 & -0.0004 & 0.97 & -0.0066 & 0.22 & 0.0016 & 0.57 & -0.0049 & 0.35 \\
\hline & -0.0016 & 0.83 & 0.0030 & 0.88 & 0.0049 & 0.43 & 0.0043 & 0.21 & -0.0100 & 0.21 & 0.0001 & 0.97 & 0.0014 & 0.48 & -0.0031 & 0.38 \\
\hline & 0.0264 & 0.17 & -0.0259 & 0.61 & -0.0128 & 0.39 & 0.0041 & 0.61 & -0.0073 & 0.70 & 0.0161 & 0.08 & -0.0008 & 0.87 & 0.0074 & 0.39 \\
\hline & & 0.03 & & 0.39 & & 0.77 & & 0.33 & & 0.04 & & 0.01 & & 0.01 & & 0.63 \\
\hline & & 0.61 & & 0.29 & & 0.14 & & 0.32 & & 0.56 & & 0.67 & & 0.66 & & 0.19 \\
\hline & & 4.94 & & 9.80 & & 4.01 & & 18.65 & & 4.68 & & 2.82 & & 2.68 & & 3.19 \\
\hline Intercept & 7.1573 & $<0.01$ & 16.5546 & $<0.01$ & 10.9446 & $<0.01$ & 0.9188 & 0.02 & 13.0189 & $<0.01$ & 6.5892 & $<0.01$ & 4.0361 & $<0.01$ & 6.3658 & $<0.01$ \\
\hline $\mathrm{GS}^{1}$ & -0.0018 & 0.85 & 0.0064 & 0.81 & 0.0037 & 0.54 & 0.0014 & 0.76 & -0.0037 & 0.65 & 0.0028 & 0.41 & 0.0022 & 0.31 & 0.0010 & 0.78 \\
\hline $\mathrm{CS}^{2}$ & 0.0117 & 0.36 & 0.0007 & 0.98 & -0.0044 & 0.59 & -0.0002 & 0.98 & -0.0004 & 0.97 & 0.0015 & 0.73 & -0.0029 & 0.32 & 0.0069 & 0.15 \\
\hline $\mathrm{RO}^{3}$ & 0.0308 & 0.05 & -0.0441 & 0.28 & -0.0163 & 0.10 & 0.0021 & 0.76 & -0.0294 & 0.03 & 0.0156 & 0.01 & 0.0060 & 0.08 & 0.0060 & 0.26 \\
\hline$P$ & & 0.02 & & 0.47 & & 0.11 & & 0.79 & & $<0.01$ & & $<0.01$ & & $<0.01$ & & 0.05 \\
\hline $\mathrm{R}^{2}$ & & 0.56 & & 0.18 & & 0.39 & & 0.08 & & 0.66 & & 0.78 & & 0.69 & & 0.46 \\
\hline \multirow[t]{2}{*}{ CV\% } & & 4.97 & & 10.07 & & 3.24 & & 20.78 & & 3.95 & & 2.20 & & 2.44 & & 2.50 \\
\hline & \multicolumn{2}{|c|}{ Lys } & \multicolumn{2}{|c|}{ Met } & \multicolumn{2}{|c|}{ Phe } & \multicolumn{2}{|c|}{ Pro } & \multicolumn{2}{|c|}{ Ser } & \multicolumn{2}{|c|}{ Thr } & \multicolumn{2}{|c|}{ Val } & & \\
\hline Intercept & 0.8147 & 0.96 & 0.0057 & 1.00 & 5.7751 & 0.40 & -0.8552 & 0.94 & 3.0353 & 0.54 & 8.4557 & 0.11 & 19.4798 & 0.02 & & \\
\hline $\mathrm{OM}$ & 0.0134 & 0.37 & 0.0011 & 0.63 & -0.0032 & 0.58 & 0.0053 & 0.61 & 0 & 1.00 & -0.0035 & 0.42 & -0.0118 & 0.07 & & \\
\hline $\mathrm{CP}$ & -0.0044 & 0.77 & 0.0006 & 0.80 & 0.0009 & 0.88 & 0.0003 & 0.98 & 0.0048 & 0.27 & -0.0042 & 0.34 & -0.0103 & 0.11 & & \\
\hline Crude fiber & -0.0013 & 0.90 & 0.0024 & 0.15 & 0.0020 & 0.61 & 0.0010 & 0.89 & 0.0022 & 0.45 & 0.0002 & 0.95 & -0.0053 & 0.21 & & \\
\hline Ether extract & -0.0275 & 0.27 & 0.0022 & 0.57 & 0.0031 & 0.74 & -0.0024 & 0.89 & 0.0049 & 0.48 & 0.0060 & 0.40 & 0.0065 & 0.52 & & \\
\hline & & 0.27 & & 0.08 & & 0.45 & & 0.94 & & 0.37 & & 0.15 & & 0.30 & & \\
\hline$R^{2}$ & & 0.35 & & 0.50 & & 0.26 & & 0.06 & & 0.30 & & 0.43 & & 0.33 & & \\
\hline CV\% & & 5.73 & & 5.85 & & 7.03 & & 10.59 & & 4.06 & & 3.83 & & 4.34 & & \\
\hline Intercept & 11.1255 & $<0.01$ & 1.5026 & $<0.01$ & 3.1494 & $<0.01$ & 4.5792 & $<0.01$ & 4.8583 & $<0.01$ & 4.2951 & $<0.01$ & 4.9041 & $<0.01$ & & \\
\hline GS & -0.0160 & 0.26 & 0.0020 & 0.37 & 0.0071 & 0.10 & -0.0093 & 0.22 & 0.0042 & 0.26 & 0.0010 & 0.80 & -0.0012 & 0.76 & & \\
\hline CS & -0.0148 & 0.42 & 0.0020 & 0.51 & 0.0107 & 0.07 & -0.0133 & 0.19 & 0.0014 & 0.78 & -0.0008 & 0.87 & 0.0014 & 0.79 & & \\
\hline RO & 0.0131 & 0.53 & 0.0013 & 0.69 & -0.0019 & 0.76 & 0.0036 & 0.74 & -0.0074 & 0.20 & 0.0064 & 0.27 & 0.0145 & 0.03 & & \\
\hline$P$ & & 0.64 & & 0.24 & & 0.08 & & 0.33 & & 0.52 & & 0.19 & & 0.01 & & \\
\hline $\mathrm{R}^{2}$ & & 0.13 & & 0.28 & & 0.41 & & 0.24 & & 0.17 & & 0.32 & & 0.58 & & \\
\hline $\mathrm{CV} \%$ & & 6.37 & & 6.72 & & 6.00 & & 9.12 & & 4.24 & & 4.03 & & 3.30 & & \\
\hline
\end{tabular}

${ }^{1} \mathrm{GS}=$ Inclusion rate of grass silage in \% of DM.

${ }^{2} \mathrm{CS}=$ Inclusion rate of corn silage in \% of DM.

${ }^{3} \mathrm{RO}=$ Inclusion rate of total roughages in $\%$ of $\mathrm{DM}$ 
in the RUP fraction, but also modified the AA profile. These results indicate that the composition of the $\mathrm{CP}_{\mathrm{M}}$ is affected by the origin of the feed protein. On the other hand, data from this study showed that the level of CP in TMR did not substantially affect the AA profile of $\mathrm{CP}_{\mathrm{M}}$ (Table 4). The inclusion rate of grass silage appeared to be a predicting factor for the AA profile of $\mathrm{CP}_{\mathrm{M}}$. Proteolysis starting after grass harvesting can affect the ratio of peptides, free AA, amides, nucleotides, and other nitrogenous compounds in the grass products (Givens and Rulquin, 2004). Great differences can exist between grass silages in the contents of CP, acid-soluble $\mathrm{CP}$, or ammonia-N (Yan and Agnew, 2004). Because most microbes prefer ammonia-N for protein synthesis (Pilgrim et al., 1970; Mathison and Milligan, 1971; Nolan et al., 1976), the composition of the ruminal population may be affected by the fractional distribution of $\mathrm{N}$ from the grass silage. In addition, additives in silages and the maturation of the grass caused a change of the content and the availability of nutrients in the feed (Cone et al., 1999; Hetta et al., 2003). This hypothesis cannot be followed any further for the present study because only total $\mathrm{N}$ was analyzed in TMR and ingredients.

During the initial adaptation phase of a Rusitec study, the total and relative percentages of different microbes may change dramatically (Prevot et al., 1994). This change, however, did not result in negative effects on the extent of fermentation. It has not been studied whether the AA profile of the microbial population changed. The range in AA pattern found for different TMR in the present study was within the range found in vivo, based on literature data (Table 6). The range of AA concentrations for microbes isolated in vitro was small in comparison with the in vivo results. Within individual studies, the ratio of AA changed only to a small extent, which suggests a laboratory effect that needs consideration in the interpretation of literature reviews. The comparison indicates that this in vitro method is suitable to describe the AA pattern of $\mathrm{CP}_{\mathrm{M}}$ in the rumen.

It has been shown repeatedly that the AA profile of different microbial fractions isolated from the rumen could show marked differences (Cecava et al., 1990; Martin et al., 1994, 1996; Rodríguez et al., 2000; Korhonen et al., 2002). The AA profile of SAM isolated from feed residues found in the present study was also different from the profile found in RM and LAM (Table 1). In accordance with Rodríguez-Prado et al. (2004), multiple regression analysis showed that the CF content of the ration has an effect on the AA composition of RM protein (Table 4) and SAM protein (Table 5).

When using a Rusitec, liquid- and solid-associated microbes can only be isolated at the end of the incuba-
Table 6. Comparison of AA pattern in microbial protein $(\text { Met }=1)^{1}$ between in vitro and in vivo studies

\begin{tabular}{llllll}
\hline & \multicolumn{2}{c}{ In vitro $^{2}$} & & \multicolumn{2}{c}{ In vivo $^{3}$} \\
\cline { 2 - 3 } \cline { 5 - 5 } acid & Minimum & Maximum & & Minimum & Maximum \\
\hline Ala & 3.1 & 4.0 & 1.6 & 7.1 \\
Arg & 2.1 & 2.7 & 0.8 & 8.0 \\
Asp & 4.6 & 5.4 & 2.8 & 6.9 \\
Cys & 0.4 & 0.5 & 0.3 & 2.5 \\
Glu & 4.9 & 6.0 & 2.7 & 7.1 \\
Gly & 2.1 & 2.5 & 1.1 & 7.4 \\
Ile & 2.0 & 2.4 & 1.2 & 3.4 \\
Leu & 3.0 & 3.6 & 1.6 & 4.9 \\
Lys & 2.9 & 3.7 & 1.5 & 7.9 \\
Phe & 1.9 & 2.3 & 1.1 & 3.0 \\
Pro & 1.3 & 1.9 & 0.8 & 2.4 \\
Ser & 1.5 & 1.9 & 1.0 & 3.0 \\
Thr & 2.1 & 2.4 & 1.2 & 3.4 \\
Val & 2.4 & 2.8 & 1.2 & 4.4 \\
\hline
\end{tabular}

${ }^{1}$ This expression was chosen to allow for a comparison between publications that had used different modes of expression.

${ }^{2}$ Results from this study ( $\mathrm{n}=16$ ).

${ }^{3}$ Data from Bergen et al., 1968; Burris et al., 1974; Cecava et al., 1988; Gabel and Poppe, 1986; Hoogenraad and Hird, 1970; Hvelplund, 1986; Ibrahim and Ingalls, 1972; Meyer et al., 1967; Purser and Buechler, 1966; Storm and Orskov, 1983; Titgemeyer et al., 1989; Williams and Dinusson, $1973(\mathrm{n}=21)$.

tion period, whereas the RM fraction represents the average population of microbes leaving the system over time. Therefore, many authors consider these microbes (RM) isolated from liquid effluent representative for the complete rumen population. It is not possible to judge whether the LAM fraction included the same microbes as the RM fraction. Comparable results for this fraction were not found in the literature. Studies have shown that substances like yeast extract, BSA, sucrose, or starch may promote protozoal growth in vitro (Hillman et al., 1991; Broudiscou et al., 1997). Under typical operation conditions, the protozoa number in a Rusitec declines rapidly within a short period (Abe and $\mathrm{Ku}$ meno, 1973; Prevot et al., 1994). Consequently, the microbes contained in liquid effluent are mainly bacteria and it is unclear whether they represent the complete microbial population. Furthermore, any protozoa remaining likely were sedimented in the $2,000 \times g$ centrifugation used to separate feed from ruminal microorganisms. Differences in the method of LAM isolation among studies make it difficult to compare results. Microbes isolated from the liquid effluent of a continuous system (Bach and Stern, 1999) may not be the same as those from the vessels in the present study.

The SAM fraction may contribute 70 to $80 \%$ of the ruminal microbial OM (Craig et al., 1987). This highlights the fact that the description of the AA composition of SAM protein is highly relevant for estimating microbial AA flow to the duodenum. However, different techniques were used to isolate SAM. Ranilla and Carro 
(2003) reported that application of the methylcellulose solution, which was used in this study at $38^{\circ} \mathrm{C}$ for 15 min, combined with homogenizing and chilling at $4^{\circ} \mathrm{C}$ for $24 \mathrm{~h}$, removed a major proportion of SAM from solid rumen content. The use of other chemicals (alcohol, formaldehyde, acids) or physical methods (chilling, homogenization, agitation with marbles; Whitehouse et al., 1994) was often avoided to retain microbial cell integrity (Rodríguez-Prado et al., 2004). Minato and Suto (1978) described the removal of different microbial species when solid ruminal contents were incubated at 4 or $38^{\circ} \mathrm{C}$. Some studies (Rodríguez et al., 2000; Yang et al., 2001; Jaurena et al., 2005) simply used cold 0.9\% (wt/vol) $\mathrm{NaCl}$ to isolate particle-associated bacteria by differential centrifugation after cooling. Craig et al. (1987) removed the microbes using a solution containing saline, formaldehyde, and Tween 80. In our study, only those SAM were considered that attached to methylcellulose at $39^{\circ} \mathrm{C}$. Martin et al. (1996) ground and pummeled the solid rumen material in a precooled $\left(4^{\circ} \mathrm{C}\right)$ Coleman buffer $(1 \mathrm{~g}$ of solid $/ 4 \mathrm{~mL})$ to dislodge SAM. Additionally, some authors distinguish between loosely and tightly associated bacteria by using different methods of isolation (Selim et al., 2002). The mentioned differences in the isolation methods make it very difficult to compare different studies in regard to SAM. It is also not clear to what extent SAM contribute to the RM fraction.

\section{CONCLUSIONS}

The AA profile of $\mathrm{CP}_{\mathrm{M}}$ is not constant when feeding different TMR. The degree of limitation of performance by the microbial supply to the duodenum of a certain AA may therefore be different between TMR. Currently, a prediction of the AA profile based on analyzed nutrients or the inclusion rate of a feedstuff is not possible with high accuracy. The AA profile of the protein from solid-associated microbes does not seem to be influenced by individual dietary factors. Different microbial fractions respond differently to TMR in the AA profile, and further investigation is needed to determine whether this is the result of differences in the microbial population. Future studies on changes in the microbial population need a strict standardization of sampling details, isolation technique, and analyses to allow better comparison of the data.

\section{ACKNOWLEDGMENT}

This study was supported by the Studienstiftung des Deutschen Volkes with a doctoral scholarship for Jeannette Boguhn, which is gratefully acknowledged.

\section{REFERENCES}

Abe, M., and F. Kumeno. 1973. In vitro simulation of rumen fermentation: Apparatus and effects of dilution rate and continuous dialysis on fermentation and protozoal population. J. Anim. Sci. 36:941-948.

Atasoglu, C., C. Valdès, C. J. Newbold, and R. J. Wallace. 1999. Influence of peptides and amino acids on fermentation rate and de novo synthesis of amino acids by mixed micro-organisms from the sheep rumen. Br. J. Nutr. 81:307-314.

Bach, A., and M. D. Stern. 1999. Effects of different levels of methionine and ruminally undegradable protein on the amino acid profile of effluent from continuous culture fermenters. J. Anim. Sci. 77:3377-3384.

Bateman, H. G., J. H. Clark, R. A. Patton, C. J. Peel, and C. G. Schwab. 2001. Accuracy and precision of computer models to predict passage of crude protein and amino acids to the duodenum of lactating cows. J. Dairy Sci. 84:649-664.

Bergen, W. G., D. B. Purser, and J. H. Cline. 1968. Effect of ration on the nutritive quality of rumen microbial protein. J. Anim. Sci. 27:1497-1501.

Boguhn, J., Kluth, H, and Rodehutscord, M. 2006. Effect of total mixed ration composition on fermentation and efficiency of ruminal microbial crude protein synthesis in vitro. J. Dairy Sci. 89:1580-1591.

Brandt, M., and K. Rohr. 1981. Beiträge zur Quantifizierung der NUmsetzungen in den Vormägen von Milchkühen 1. Mitteilung: Bestimmung des Mikrobenstickstoffs im Duodenalchymus mit Hilfe von $15 \mathrm{~N}$. Z. Tierphysiol. Tierernahr. Futtermittelkd. 46:39-48.

Broudiscou, L. P., Y. Papon, M. Fabre, and A. F. Broudiscou. 1997. Maintenance of rumen protozoa population in a dual outflow continuous fermenter. J. Sci. Food Agric. 75:273-280.

Burris, W. R., N. W. Bradley, and J. A. Boling. 1974. Amino acid availability of isolated rumen microbes as affected by protein supplement. J. Anim. Sci. 38:200-205.

Calsamiglia, S., M. D. Stern, and J. L. Firkins. 1995. Effects of protein source on nitrogen metabolism in continuous culture and intestinal digestion in vitro. J. Anim. Sci. 73:1819-1827.

Carro, M. D., and E. L. Miller. 2002. Comparison of microbial markers $\left({ }^{15} \mathrm{~N}\right.$ and purine bases) and bacterial isolates for the estimation of rumen microbial protein synthesis. Anim. Sci. 75:315-321.

Cecava, M. J., N. R. Merchen, L. L. Berger, and G. C. Fahey. 1988. Effects of dietary energy level and protein source on site of digestion and duodenal nitrogen and amino acid flows in steers. J. Anim. Sci. 66:961-974.

Cecava, M. J., N. R. Merchen, L. C. Gay, and L. L. Berger. 1990. Composition of ruminal bacteria harvested from steers as influenced by dietary energy level, feeding frequency, and isolation techniques. J. Dairy Sci. 73:2480-2488.

Clark, J. H., T. H. Klusmeyer, and M. R. Cameron. 1992. Microbial protein synthesis and flows of nitrogen fractions to the duodenum of dairy cows. J. Dairy Sci. 75:2304-2323.

Cone, J. W., A. H. van Gelder, I. A. Soliman, H. de Visser, and A. M. van Vuuren. 1999. Different techniques to study rumen fermentation characteristics of maturing grass and grass silage. J. Dairy Sci. 82:957-966.

Craig, W. M., G. A. Broderick, and D. B. Ricker. 1987. Quantitation of microorganisms associated with the particulate phase of ruminal ingesta. J. Nutr. 117:56-62.

Czerkawski, J. W., and G. Breckenridge. 1977. Design and development of a long-term rumen simulation technique (Rusitec). Br. J. Nutr. 38:371-384.

Dijkstra, J., J. France, and D. R. Davies. 1997. Different mathematical approaches to estimating microbial protein supply in ruminants. J. Dairy Sci. 81:3370-3384.

Gabel, M., and S. Poppe. 1986. Untersuchungen zum Protein- und Aminosäurenumsatz im Verdauungstrakt bei wachsenden Jungbullen 5. Mitteilung: Fluß von Aminosäuren ins Duodenum. Arch. Tierernahr. 36:429-454. 
Givens, D. I., and H. Rulquin. 2004. Utilisation by ruminants of nitrogen compounds in silage-based diets. Anim. Feed Sci. Technol. 114:1-18.

Greenwood, R. H., and E. C. Titgemeyer. 2000. Limiting amino acids for growing Holstein steers limit-fed soybean hull-based diets. J. Anim. Sci. 78:1997-2004.

Guzzon, P., B. Stefanon, C. R. Mills, and P. Susmel. 1997. Microbial amino acid yield from in vitro incubation of cellulose or starch with rumen fluid. Anim. Feed Sci. Technol. 67:37-47.

Hannah, S. M., M. D. Stern, and F. R. Ehle. 1986. Evaluation of a dual flow continuous culture system for estimating bacterial fermentation in vivo of mixed diets containing various soya bean products. Anim. Feed Sci. Technol. 16:51-62.

Hetta, M., J. W. Cone, A.-M. Gustavsson, and K. Martinsson. 2003. The effect of additives in silages of pure timothy and timothy mixed with red clover on chemical composition and in vitro rumen fermentation characteristics. Grass Forage Sci. 58:249-257.

Hillman, K., A. G. Williams, and D. Lloyd. 1991. Evaluation of matrices in the rumen simulation technique (RUSITEC) for the maintenance of ciliate protozoa. Lett. Appl. Microbiol. 12:129-132.

Hoogenraad, N. J., and F. J. R. Hird. 1970. The chemical composition of rumen bacteria and cell walls from rumen bacteria. Br. J. Nutr. 24:119-127.

Hvelplund, T. 1986. The influence of diet on nitrogen and amino acid content of mixed rumen bacteria. Acta Agric. Scand. 36:325-331.

Ibrahim, E. A., and J. R. Ingalls. 1972. Microbial protein biosynthesis in the rumen. J. Dairy Sci. 55:971-978.

Jaurena, G., J. M. Moorby, and D. R. Davies. 2005. Efficiency of microbial protein synthesis on red clover and ryegrass silages supplemented with barley by rumen simulation technique (RUSITEC). Anim. Feed Sci. Technol. 118:79-91.

Kim, C. H., J. J. Choung, and D. G. Chamberlain. 1999. Determination of the first-limiting amino acid for milk production in dairy cows consuming a diet of grass silage and a cereal-based supplement containing feather meal. J. Sci. Food Agric. 79:1703-1708.

Korhonen, M., S. Ahvenjärvi, A. Vanhatalo, and P. Huhtanen. 2002. Supplementing barley or rapeseed meal to dairy cows fed grassred clover silage: II. Amino acid profile of microbial fractions. J. Anim. Sci. 80:2188-2196.

Lescoat, P., and D. Sauvant. 1995. Development of a mechanistic model for rumen digestion validated using the duodenal flow of amino acids. Reprod. Nutr. Dev. 35:45-70.

Martin, C., A. G. Williams, and B. Michalet-Doreau. 1994. Isolation and characteristics of the protozoal and bacterial fractions from bovine ruminal contents. J. Anim. Sci. 72:2962-2968.

Martin, C., L. Bernard, and B. Michalet-Doreau. 1996. Influence of sampling time and diet on amino acid composition of protozoal and bacterial fractions from bovine ruminal contents. J. Anim. Sci. 74:1157-1163.

Mason, V. C., M. Rudemo, and S. Bech-Andersen. 1980. Hydrolysate preparation for amino acid determinations in feed constituents 6 . The influence of phenol and formic acid on the recovery of amino acids from oxidized feed protein. Z. Tierphysiol. Tierernahr. Futtermittelkd. 43:35-48.

Mathison, G. W., and L. P. Milligan. 1971. Nitrogen metabolism in sheep. Br. J. Nutr. 25:351-366.

Meyer, R. M., E. E. Bartley, C. W. Deyoe, and V. F. Colenbrander. 1967. Feed Processing: 1. Ration effects on rumen microbial protein synthesis and amino acid composition. J. Dairy Sci. 50:1327-1332.

Minato, H., and T. Suto. 1978. Technique for fractionation of bacteria in rumen microbial ecosystem. II. Attachment of bacteria isolated from bovine rumen to cellulose powder in vitro and elution of bacteria attached therefrom. J. Gen. Appl. Microbiol. 24:1-16.

Naumann, C., and R. Bassler. 1976. VDLUFA-Methodenbuch, Vol. III. Die chemische Untersuchung von Futtermitteln. Loose leaflet collection with supplements from 1983, 1988, 1993, and 1997. VDLUFA-Verlag, Darmstadt, Germany.

Nolan, J. V., B. W. Norton, and R. A. Leng. 1976. Further studies of the dynamics of nitrogen metabolism in sheep. Br. J. Nutr. $35: 127-147$.

O'Connor, J. D., C. J. Sniffen, D. G. Fox, and W. Chalupa. 1993. A net carbohydrate and protein system for evaluating cattle diets: IV. Predicting amino acid adequacy. J. Anim. Sci. 71:1298-1311.

Pilgrim, A. F., F. V. Gray, R. A. Weller, and C. B. Belling. 1970. Synthesis of microbial protein from ammonia in sheep's rumen and the proportion of dietary converted into microbial nitrogen. Br. J. Nutr. 24:589-598.

Prevot, S., J. Senaud, J. Bohatier, and G. Prensier. 1994. Variation in the composition of the ruminal bacterial microflora during the adaptation phase in an artificial fermentor (Rusitec). Zool. Sci. (Tokyo) 11:871-878.

Purser, D. B., and S. M. Buechler. 1966. Amino acid composition of rumen organisms. J. Dairy Sci. 49:81-84.

Ranilla, M. J., and M. D. Carro. 2003. Diet and procedures used to detach particle-associated microbes from ruminal digesta influence chemical composition of microbes and estimation of microbial growth in Rusitec fermenters. J. Anim. Sci. 81:537-544.

Rodríguez, C. A., J. González, M. R. Alvir, J. L. Repetto, C. Centeno, and F. Lamrani. 2000. Composition of bacteria harvested from the liquid and solid fractions of the rumen of sheep as influenced by feed intake. Br. J. Nutr. 84:369-376.

Rodríguez-Prado, M., S. Calsamiglia, and A. Ferret. 2004. Effects of fiber content and particle size of forage on the flow of microbial amino acids from continuous culture fermenters. J. Dairy Sci. 87:1413-1424.

Selim, A. S. M., J. Pan, T. Suzuki, K. Ueda, Y. Kobayashi, and K. Tanaka. 2002. Postprandial changes in particle associated ruminal bacteria in sheep fed ammoniated rice straw. Anim. Feed Sci. Technol. 102:207-215.

Storm, E., and E. R. Ørskov. 1983. The nutritive value of rumen microorganisms in ruminants 1 . Large -scale isolation and chemical composition of rumen micro-organisms. Br. J. Nutr. 50:463-470.

Timmler, R., and M. Rodehutscord. 2003. Dose-response relationship for valine in the growing White Peking duck. Poult. Sci. 82:1755-1762.

Titgemeyer, E. C., N. R. Merchen, and L. L. Berger. 1989. Evaluation of soybean meal, corn gluten meal, blood meal and fish meal as sources of nitrogen and amino acids disappearing from the small intestine of steers. J. Anim. Sci. 67:262-275.

Whitehouse, N. L., V. M. Olson, C. G. Schwab, W. R. Chesbro, K. D. Cunningham, and T. Lykos. 1994. Improved techniques for dissociating particle-associated mixed ruminal microorganisms from ruminal digesta solids. J. Anim. Sci. 72:1335-1343.

Williams, P. P., and W. E. Dinusson. 1973. Amino acid and fatty acid composition of bovine ruminal bacteria and protozoa. J. Anim. Sci. 36:151-155.

Yan, T., and R. E. Agnew. 2004. Prediction of nutritive values in grass silages: I. Nutrient digestibility and energy concentrations using nutrient compositions and fermentation characteristics. J. Anim. Sci. 82:1367-1379.

Yang, W. Z., K. A. Beauchemin, and L. M. Rode. 2001. Effect of dietary factors on distribution and chemical composition of liquid- or solid-associated bacterial populations in the rumen of dairy cows. J. Anim. Sci. 79:2736-2746. 